\title{
Dobór czytań biblijnych w okresie przygotowawczym do Wielkiego Postu w Kościele prawosławnym
}

\author{
The Selection of Biblical Readings in the Preparatory Period \\ before Lent in the Orthodox Church
}

\author{
ADAM MAGRUK \\ Chrześcijańska Akademia Teologiczna w Warszawie \\ admagruk@wp.pl, ORCID: 0000-0001-9468-624X
}

Streszczenie: Poniższy artykuł dotyka zagadnień doboru, miejsca i kolejności perykop z Pisma Świętego, które rokrocznie recytowane są w prawosławnych świątyniach w okresie przygotowawczym do wyjątkowego okresu roku liturgicznego, jakim jest Wielki Post. W artykule zastosowano głównie metodę opisową. Publikacja wskazuje na logiczne i dydaktyczne umiejscowienie czytań biblijnych u progu Wielkiego Postu.

Słowa kluczowe: Wielki Post, prawosławie, Pismo Święte

Abstract: The article deals with the selection and sequence of the pericopes from the Sacred Scriptures that are recited every year in Orthodox churches in the period of preparation for the special season of the liturgical year known as Lent. The article mainly uses the descriptive method. The publication points to the logical and didactic location of the biblical readings at the threshold of Lent.

Keywords: Lent, Orthodoxy, Sacred Scripture

Kościół prawosławny wyróżnia cztery okresy postów wielodniowych ${ }^{1}$. Poprzedzają one święta: Bożego Narodzenia (25 XII) $)^{2}$, apostołów Piotra i Pawła (29 VI) ${ }^{3}$, Zaśnięcia Bogurodzicy (15 VIII) $)^{4}$ oraz Paschy Pańskiej. Ostatni z wymienionych - Wielki Post - można podzielić na trzy części. Pierwsza inauguruje poniedziałek po tzw. niedzieli przebaczenia win i trwa aż do piątku szóstego tygodnia postu (40 dni). Po nim

1 W Kościele prawosławnym funkcjonują również posty jednodniowe, do których należą prawie wszystkie środy i piątki (za wyjątkiem tygodni: po niedzieli o celniku i faryzeuszu, po niedzieli o Sądzie Ostatecznym, paschalnego, po święcie Pięćdziesiątnicy, okresu od 25 grudnia do 4 stycznia), święta: Ścięcia Głowy św. Jana Chrzciciela (29 sierpnia), Podwyższenia Krzyża Pańskiego (14 września) czy wigilii Chrztu Pańskiego (5 stycznia).

2 Rozpoczyna się 15 listopada i trwa 40 dni.

3 Jego początek to poniedziałek po niedzieli Wszystkich Świętych. Jego długość uzależniona jest od daty Paschy i waha się od 8 do 42 dni.

4 Pierwszy dzień dwutygodniowego postu przypada na 1 sierpnia. 
następują dwa dni pełniące niejako ogniwo łączące z Wielkim Tygodniem, mianowicie sobota Łazarza oraz Niedziela Palmowa, po której wierni rozpoczynają celebrację Męki Pańskiej.

Wielki Post posiada ponadto długi okres przygotowawczy ${ }^{5}$, w którym kardynalne miejsce zajmują niedziele. Najbardziej charakterystyczną cechą tych dni jest dobór perykop ewangelicznych, a mianowicie o: Zacheuszu, celniku i faryzeuszu, synu marnotrawnym, Sądzie Ostatecznym. Cały ten cykl zamyka niedziela seropustna (przebaczenia).

Pod względem liturgicznym przedstawiona kolejność czytań ma własną historię umiejscowienia w kalendarzu roku kościelnego. Do ostatecznego ukształtowania się obecnego porządku tego okresu przyczyniły się dwie tradycje: jerozolimska oraz konstantynopolitańska. Najstarsze rękopisy ksiąg liturgicznych datują pojawienie się niedzieli seropustnej i niedzieli o Sądzie Ostatecznym już na VI w. Wspomina o nim m.in. gruzińskie tłumaczenie Lekcjonarza jerozolimskiego (VII w.) $)^{6}$. Zapożyczając sposób czytań z Palestyny, konstantynopolitańska tradycja w X w. dodała do niego niedziele: o synu marnotrawnym, o celniku i o faryzeuszu. Z kolei czytanie historii o Zacheuszu musiało pojawić się w stolicy Bizancjum już po ostatecznym sformułowaniu się księgi Triodionu Postnego. Dlatego właśnie ostatni z wymienionych epizodów ewangelicznych nie posiada w swojej treści własnego nabożeństwa.

Celem tego artykułu jest ogólna charakterystyka każdej z niedziel oraz innych, najbardziej wymownych dni przedpościa. Wskazany zostanie również aspekt duchowy doboru biblijnej lektury liturgii, jak również jej ścisła korelacja z czasem postu.

\section{Niedziela o Zacheuszu}

Pierwszym zwiastunem Wielkiego Postu, przypadającym pięć tygodni przed jego początkiem, jest tzw. niedziela o Zacheuszu, kiedy czytana jest historia spotkania Chrystusa z naczelnikiem celników o tym właśnie imieniu (Łk 19,1-10) ${ }^{7}$. Jej główny bohater zapragnął za wszelką cenę zobaczyć przechodzącego Nauczyciela. Z uwagi jednak na swój niski wzrost oraz zgromadzony tłum nie mógł tego uczynić. Nie

5 Pozostałe wielodniowe posty takiego okresu nie posiadają. Warto też dodać, że w Kościele rzymskokatolickim jeszcze do czasów reformy liturgicznej Soboru Watykańskiego II praktykowane było również tzw. przedpoście, które poprzedzało właściwy Wielki Post. Ów okres liturgiczny obejmował trzy niedziele poprzedzające środę popielcową. Przepisy liturgiczne jasno stwierdzały, że w okresie przedpościa post jeszcze nie obowiązuje. Duchowni sprawowali nabożeństwa w szatach koloru fioletowego. Nie śpiewano już wówczas radosnego „Alleluja” ani nie odmawiano hymnu "Chwała na wysokości Bogu”, natomiast liturgia koncentrowała się na tematyce upadku rodzaju ludzkiego, a zwłaszcza grzechu pierworodnego i jego konsekwencji. Zob. Blaza, „Karnawał jako przygotowanie”.

6 Кекелидзе, Иерысалимский Канонар, 56.

7 Cytaty Pisma Świętego podano za Biblią Tysiąclecia. 
zważając na ludzkie komentarze, wchodzi na drzewo sykomory, aby ujrzeć Jezusa. Apostoł Łukasz używa w tym miejscu greckiego czasownika i $\delta \varepsilon i v$, który sugeruje, że w tym momencie chodziło nie tylko o zwyczajne ujrzenie oczyma, lecz głębsze sercem - poznanie Boga ${ }^{8}$. Opowiadanie akcentuje potrzebę zrodzenia w sercu pragnienia spotkania w swoim życiu Jezusa, bez względu na opinię, krytykę czy dyskredytację ze strony innych. To również pierwszy krok, który powinien uczynić każdy, kto chce godnie spotkać i „pokłonić się świętemu Chrystusowemu Zmartwychwstaniu”. Wymowne w tym aspekcie wydają się być ponadto słowa Syna Bożego: „Zejdź prędko z tego drzewa" (por. Łk 19,5). Funkcjonuje bowiem przekonanie, że owoce wspomnianej sykomory są łudząco podobne do rajskich fig ${ }^{10}$. W Edenie ich spożycie doprowadziło do upadku człowieka. W czytaniu o Zacheuszu również staje się ono niejako symbolem grzechu. Dlatego właśnie, wzywając do szybkiego zstąpienia na ziemię, Chrystus nawołuje Zacheusza do zerwania z dotychczasowym życiem w nieprawości (por. $1 \mathrm{~J}$ 3,4) i wsłuchania się w głos Boga. To także jedno z przesłań, które niesie ze sobą okres postu.

Co ciekawe, ewangelista Łukasz umieszcza to wydarzenie w trakcie trzeciej i zarazem ostatniej podróży Jezusa do Jerozolimy, zakończonej dla Niego śmiercią krzyżową i chwalebnym Zmartwychwstaniem. Można w tym miejscu zaryzykować stwierdzenie, że już od tego dnia rozpoczyna się wspólna droga wiernych ze Zbawicielem do paschalnej nocy.

\section{Niedziela o celniku i faryzeuszu}

Podczas kolejnej - poprzedzającej Wielki Post - niedzieli w prawosławnych świątyniach czytane jest opowiadanie o faryzeuszu i celniku (Łk 18,10-14) ${ }^{11}$. Pierwszy z nich odważnie stwierdza, że w pełni przestrzega Prawa, pogardzając jednocześnie stojącym obok celnikiem. Cechuje go pewność siebie i zgubna dla duszy pycha. Drugi natomiast jedynie prosi o Boże miłosierdzie. Tym samym pokora staje się dla celnika chwałą, „źródłem wszelkiego piękna, doskonałości i dobroci. Jego postawa uczy, że każdy, kto zbliża się do Boga i poznaje Go, okazuje się uczestnikiem Bożej pokory i zostaje przez nią upiększony”12. Za pośrednictwem tej perykopy Kościół przygoto-

\footnotetext{
8 Bluj, „Głębokie spojrzenie”.

9 Zob. „W Świętą i Wielką Niedzielę Paschy”.

10 Niektóre z przekazów podają, że rosnące w Edenie drzewo poznania dobra i zła było figowcem. Zob. „Synaksarion niedzieli seropustnej”; Świeżyński, „Hermeneutyczna próba rekonstrukcji ontologii”, 102.

11 Od tego dnia aż do Wielkiej Soboty podczas nabożeństw używana jest księga Triodionu Postnego, zawierająca teksty liturgiczne na każdy dzień tego okresu. Za ich autorów uważa się m.in. świętych: Kosmasa z Maiumy oraz Teodora i Józefa Studytów.

12 Schmemann, Wielki Post, 22.
} 
wuje wiernych na czekającą ich w poście duchową bitwę z własnymi słabościami, jak też nawołuje do wyzwolenia się z żądz, które zadomowiły się w ludzkiej duszy.

Idący na wojnę żołnierze - poucza wymownie autor Synaksarionu ${ }^{13}$ - najpierw przechodzą ćwiczenia pod kierunkiem dowódców wojskowych, aby oczyściwszy oręż [...] usunęli wszelkie przeszkody i dokładnie przygotowali się do walki. Jeszcze przed rozpoczęciem działan wojennych dowódcy wielokrotnie cytują im dewizy bojowe, przypowieści, opowiadania, rozpalające w nich bojowego ducha oraz wypędzające wszelkie lenistwo, bojaźń, zniechęcenie i inne zło. Tak samo święci Ojcowie już teraz ogłaszają nadchodzącą w poście bitwę z demonami, abyśmy wyzwolili się z żądz, które zadomowiły się w duszy [...], a następnie postarali się zdobyć te cnoty, których nie mamy, i w ten sposób gotowi, w pełnym rynsztunku, przystąpili do wysiłków postnych.

W tym właśnie kontekście ewangeliczna przypowieść przypomina, że jedną z głównych broni w tej duchowej walce będzie pokora ${ }^{14}$. Zdaniem św. Jana Chryzostoma, jeżeli pycha swym ciężarem zatapia sprawiedliwość, to przeciwna jej pokora włada siłą przezwyciężania ciężaru grzechu i wiedzie ćwiczącego się w niej do Boga. Dlatego też człowiek, jeśli czyni wiele dobrego, uważa, że ma prawo tym się chwalić, utraci owoc swojej modlitwy, natomiast kiedy posiada na sumieniu ciężar tysiąca win, jeżeli uważa siebie za najmniejszego ze wszystkich, osiągnie wielkie zaufanie $\mathrm{w}$ oczach Boga ${ }^{15}$. Tym samym przekroczenie progu postu pozostanie bezowocne bez zmiany stosunku do drugiego człowieka, zaprzestania jego osądzania oraz uznania z pokorą własnej grzeszności i słabości ${ }^{16}$.

\section{Niedziela o synu marnotrawnym}

W następną niedzielę przed Wielkim Postem w świątyniach prawosławnych recytowana jest przypowieść o synu marnotrawnym (Łk 15,11-32), która wskazuje na pojęcie i siłę nawrócenia, a przede wszystkim skruchy, w języku greckim $\mu \varepsilon \tau$ ávola, dosłownie: „przemiana umysłu”, „zmiana sposobu myślenia oraz mentalności”. Ten przełomowy moment w życiu syna marnotrawnego, Ewangelia Łukasza określa charakterystycznym zwrotem: દic દ̇avtòv $\delta \grave{\varepsilon} \dot{\varepsilon} \lambda \theta \omega \dot{v}$ („przyszedł do siebie”). Innymi słowy $\mu \varepsilon \tau$ ć́voı nie jedynej prawidłowej drogi, która prowadzi w objęcia Boga. Ta biblijna historia

\footnotetext{
Synaksarion - księga zawierająca duchowe pouczenia na każdy dzień roku liturgicznego.

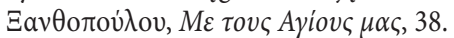

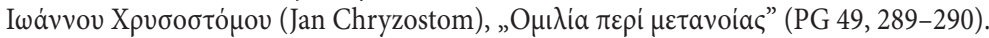

Kobeszko, „Przedpoście: zapomniany i nietypowy czas”.
} 
upatruje sens postu w pielgrzymowaniu i doświadczeniu skruchy, tj. powrotu do ojcowskiego domu ${ }^{17}$, które uwarunkowane jest uświadomieniem sobie tego, jak bardzo swoim postępowaniem „oddaliłem się” od Boga - źródła i dawcy prawdziwego życia.

Syn marnotrawny okazuje się obrazem zarówno całego upadłego rodzaju ludzkiego, jak i każdego grzesznego człowieka z osobna. Z drugiej strony ukazane zostaje nieskończone miłosierdzie Ojca Niebieskiego wobec kajających się grzeszników. „Tak samo, powiadam wam, radość powstaje u aniołów Bożych z jednego grzesznika, który się nawraca” (Łk 15,10) ${ }^{18}$. Z tego powodu ta biblijna historia mogłaby być również śmiało nazwana „przypowieścią o miłosiernym Ojcu”. Nieprzypadkowo nazwano ją „Ewangelią z Ewangelii”, zaś wśród egzegetów spotkać można odważne przekonanie, iż jeśliby ze wszystkich Ewangelii pozostała jedynie ta przypowieść, to wystarczyłaby ona do pełnego zobrazowania niewyczerpanej miłości Boga do człowieka ${ }^{19}$.

Za pośrednictwem tego jednego z najpiękniejszych tekstów liturgicznych Kościół, wraz z tytułowym bohaterem nowotestamentowego opowiadania, zaprasza do wezwania:

Objęcia ojcowskie otwórz dla mnie, poszczącego, marnotrawnie spędziłem moje życie, na bogactwo niewyczerpane patrząc Twych zlitowań, Zbawco, teraz oto ukorzonego nie odrzuć mego serca, do Ciebie bowiem, Panie, wołam z rozrzewnieniem: „Ojcze, zgrzeszyłem na niebo i przed Tobą!"20.

Zastanawiać może ponadto reakcja starszego syna, którego serce na widok uczty wydanej przez ojca na cześć rozpustnego brata napełniło się goryczą, gniewem i zawiścią. Interesujący jest również fakt, iż Łukasz nie pisze, jaki był finał tego opowiadania w przypadku starszego syna. Prawdopodobnie w ten sposób ewangelista chciał, aby każdy czytelnik tej przypowieści zastanowił się, w jaki sposób postąpiłby będąc na jego miejscu.

W dniach od poniedziałku do piątku tego tygodnia przed Wielkim Postem czytana jest Ewangelia Marka. Traktuje ona o triumfalnym wjeździe do Jerozolimy, zdradzie Judasza, Ostatniej Wieczerzy, modlitwie w Gestemanii, sądzie przed Sanhedrynem oraz ukrzyżowaniu i śmierci Chrystusa (Mk 11,1-11; 14,10-15,1; 15,22-25.33-41). Powód, dla którego brzmią właśnie te fragmenty zostanie przedstawiony poniżej.

\footnotetext{
17 Schmemann, Wielki Post, 24.

18 Ignacy Brianczaninow, „Rozważania w niedzielę o synu marnotrawnym”, 2-3.

19 Za Nektariusz (Antonopulos), Powrót. Nawrócenie i spowiedź, 4.

20 Zob. „Katyzma poetycka po 3 pieśni kanonu”.
} 


\section{Niedziela o Sądzie Ostatecznym}

W przedostatnią niedzielę przed Wielkim Postem Kościół proponuje uwadze wiernych relację o Jezusowej Paruzji (Mt 25,31-46). Jej tematem wiodącym jest międzyludzka relacja, która przekłada się na więź z Bogiem. Chrystus wyraźnie poucza, że kryterium osądu człowieka będzie poziom jego miłości wobec bliźniego. Mając na uwadze ilustrację Sądu Ostatecznego, św. Bazyli Wielki przestrzega:

Nie ograniczaj postu jedynie do powstrzymywania się od konkretnych pokarmów, gdyż prawdziwym postem jest powstrzymywanie się od złego. „Rozerwij kajdany niesprawiedliwości” (Iz 58,6). Wybacz bliźniemu smutek, który wywołał w tobie. „Nie pośćcie tak, jak dziś czynicie, żeby się rozlegał zgiełk wasz na wysokości” (Iz 58,4). Nie jesz mięsa, a brata swego «zjadasz», nie pijesz wina, lecz usta twoje pełne są wulgaryzmów ${ }^{21}$.

Umieszczenie tej właśnie perykopy na kilka dni przed początkiem Wielkiego Postu to swego rodzaju zadanie do wypełnienia na cały nadchodzący okres. Identyczne wersety ewangeliczne czytane będą ponownie w Wielki Wtorek jako pytanie skierowane do wiernych o to, w jaki sposób urzeczywistnili oni w tym wyjątkowym okresie Chrystusowe wezwanie do nakarmienia głodnego, napojenia spragnionego, odwiedzenia cierpiącego itd.

Niedziela o Sądzie Ostatecznym nosi również miano „mięsopustna”. Tego dnia bowiem wierni spożywają mięso po raz ostatni przed świętem Paschy Pańskiej. Tym sposobem Kościół sukcesywnie przyzwyczaja również ludzkie ciało do „wstrzemięźliwości pokarmowej”, a co za tym idzie - skromniejszych posiłków²2. Do tego aspektu nawiązuje także lektura Pierwszego Listu do Koryntian, wyznaczona na ten dzień $(8,8-9,2)$. Święty Paweł stanowczo stwierdza, że „przecież pokarm nie przybliża człowieka do Boga. Ani nie będziemy ubożsi, gdy przestaniemy jeść, ani też jedząc nie wzrośniemy w znaczenie [...]" (1 Kor 8,8). Jeśli jednak pokarm jest w stanie zgorszyć bliźniego, Apostoł Narodów gotów jest zrezygnować z mięsa na zawsze.

W poniedziałek, wtorek i czwartek po niedzieli mięsopustnej ponownie czyta się opowiadania o ostatnich dniach ziemskiego życia Chrystusa, tym razem z Ewangelii Łukasza $^{23}$. Opisane przez ewangelistę fakty pokrywają się niemal całkowicie z pasyjnymi wydarzeniami, o których „przed tygodniem” wspominał św. Marek. Jedyna różnica polega na tym, że na kilka dni przed początkiem Wielkiego Postu mowa jest również o pogrzebie Jezusa. Zarówno w pierwszym, jak i drugim przypadku Kościół wskazuje na ostateczny cel nadchodzącego okresu, jakim jest przeżywanie Chrystu-

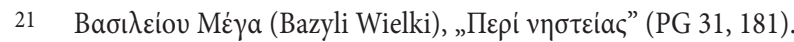

22 W czasie Wielkiego Postu wierni powstrzymują się od pokarmów pochodzenia zwierzęcego. Spożywanie oleju natomiast ogranicza się jedynie do sobót i niedziel, zaś ryb - do świąt Zwiastowania Bogurodzicy oraz Wjazdu Chrystusa do Jerozolimy.

23 Poniedziałek: Łk 19,29-40 z 22,7-39; wtorek: 22,39-42 oraz 22,45-23,1; czwartek: 23,1-34.44-56. 
sowej męki oraz jej następstwa - nocy paschalnej. Na podobieństwo zwyczaju triumfalnego niesienia przed władcą zdobytych na wojnie chorągwi, które są widocznym znakiem jego wygranej, wierni jeszcze przed rozpoczęciem duchowych zmagań dostrzegają symbol zwycięstwa nad śmiercią - krzyż. Interesującą refleksją na ten temat dzieli się Marek Blaza:

Opis ten kończy się na złożeniu Jezusa do grobu. A zatem opisy zawarte w Ewangeliach czytanych w dwóch ostatnich tygodniach przedpościa urywają się na wydarzeniach Wielkiej Soboty. Przesłanie tych dwóch ostatnich tygodni przedpościa jest jasne: aby można było kontynuować ów opis i przejść do radości zmartwychwstania Chrystusa, trzeba przejść przez trudną drogę Wielkiego Postu. Kto nie podejmie tego trudu, ten poza grób Wielkiej Soboty nie wyjdzie ${ }^{24}$.

Zadaniem pasyjnej ewangelii w okresie przygotowawczym do Wielkiego Postu jest zatem pobudzenie do osobistej walki z grzechem, którego pokonanie uwarunkowane jest podążaniem za Chrystusem na Golgotę i zstąpieniem wraz z Nim do grobu.

W środę i piątek analizowanego tygodnia liturgia nie jest sprawowana. Wszystkie nabożeństwa tych dni są niemal identyczne z tymi, które sprawowane są w aliturgiczne ${ }^{25}$ dni powszednie właściwego dla okresu Wielkiego Postu. Tym sposobem Kościół pokazuje wiernym, w jaki sposób także z liturgicznego punktu widzenia zmieni się codzienny modlitewny porządek ${ }^{26}$. Podczas nabożeństw szóstej godziny kanonicznej i wieczerni ${ }^{27}$, kalendarz kościelny przewiduje kolejno czytania z ksiąg Joela $(2,12-26 ; 3,12-21)$ oraz Zachariasza $(8,7-17.19-23)^{28}$. Perykopy pierwszej z nich wzywają do nawrócenia się na zmierzającą ku Bogu drogę. Prowadzi ona przez post, duchowy płacz i lament, które są w mocy sprowadzić na człowieka miłosierdzie Stwórcy, pod warunkiem, że będą iść w parze z serdeczną skruchą ${ }^{29}$. Zachariasz z kolei stwierdza, że pokładanie nadziei w Panu, umiłowanie prawdy i pokoju oraz wypełnienie przykazania miłości zapewni światu dobrobyt $t^{30}$. Podobnej tematyce poświęcona jest ewangelia liturgii soboty tego tygodnia. Mowa w niej m.in. o potrzebie dzielenia się z potrzebującym. Ponadto w jej skład weszła również Modlitwa Pańska, która w swym przekazie odwołuje się do dwóch kardynalnych przykazań Chrystusa: miłości wobec Boga i bliźniego (Mt 6,1-13) ${ }^{31}$. Jej trzy początkowe prośby odnoszą się

\footnotetext{
24 Blaza, „Karnawał jako przygotowanie”.

25 Aliturgiczny - przymiotnik używany w odniesieniu do dnia, kiedy Eucharystia nie jest sprawowana.

26 W czasie postu pełna liturgia eucharystyczna sprawowana jest jedynie w soboty i niedziele.

27 Wieczernia - odpowiednik nieszporów w tradycji zachodniej.

28 Никулина, Богослужебный устав, 70.

29 Виссарион, Толкование на паримии, II, 654.

30 Виссарион, Толкование на паримии, II, 713.

31 Por. Mt 22,35-40; Mk 12,30-31.
} 
do pierwszego z zaleceń Jezusa, pozostałe zaś ukazują drogę do zachowania zdrowych międzyludzkich relacji ${ }^{32}$.

\section{Niedziela przebaczenia win ${ }^{33}$}

Ostatnia niedziela przygotowawcza do Wielkiego Postu posiada kilka nazw: „wygnania Adama z raju” ${ }^{34}$, „seropustna” ${ }^{35}$ oraz „przebaczenia win”. Jej liturgiczne czytanie (Mt 6,14-19) w pierwszej kolejności nawiązuje do trzeciej z wymienionych nazw: "Jeśli bowiem odpuszczacie ludziom przewinienia ich, odpuści i wam Ojciec wasz niebiański. Jeśli zaś nie odpuszczacie ludziom ich przewinień, to i Ojciec wasz nie odpuści przewinień waszych" (Mt 6,14-15). Tego dnia prawosławna tradycja zaleca wiernym wzajemne zwrócenie się z prośbą o darowanie przewinień i zaniedbań, których dopuścili się wobec bliźniego. Konstanty Bondaruk radzi, by wstępując w dni Wielkiego Postu, zwanego w Kościele prawosławnym również „wiosną duchową", rozpocząć go z czystą kartą, niejako od zera, bez brzemienia zaszłości i nieuregulowanych zobowiązań. Czas trwania Wielkiego Postu stanowi dziesiątą część całego roku. Człowiek przynosi Bogu niejako dar biblijnej dziesięciny. W Kazaniu na Górze Jezus Chrystus wyraźnie mówi jednak: „Jeśli przyniesiesz dar twój przed ołtarz i tam wspomnisz, że brat twój ma coś przeciw tobie, zostaw tam dar twój przed ołtarzem, a najpierw idź i pojednaj się z bratem swoim" (Mt 5,23-24) ${ }^{36}$. Pouczenia ewangeliczne akcentują bardzo wyraźnie, że owocne rozpoczęcie dzieł Bożych stanie się nierealne, jeżeli zabraknie zgody w międzyludzkich relacjach ${ }^{37}$.

W następnej kolejności Chrystus ilustruje, jak w praktyce powinien wyglądać prawdziwy post: „Ty zaś, gdy pościsz, namaść swoją głowę i twarz swoją umyj, tak byś nie ludziom pokazywał, że pościsz, lecz Ojcu twemu, Który jest w skrytości, i Ojciec twój widzący, co zakryte, nagrodzi cię" (Mt 6,17-18). Postny trud będzie pozbawiony jakiegokolwiek sensu, jeżeli zabraknie w nim miłości, skromności i prostoty serca.

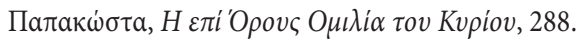
niedzieli seropustnej".

Szerzej na ten temat patrz: Magruk, „Teologiczno-liturgiczny wymiar ostatniej niedzieli”, 205-216.

W tekstach liturgicznych tej niedzieli bardzo mocno akcentowany jest starotestamentowy opis upadku człowieka oraz żalu, który odczuwał on po opuszczeniu raju. Jeden z nich brzmi następująco: „Adam siadł naprzeciw raju i łkając opłakiwał swoją nagość: Biada mi, którego pokonało oszustwo złego i zostałem okradziony oraz pozbawiony chwały! Biada mi, w prostocie nagiemu, a teraz zakłopotanemu! O raju, nie nasycę się już twoją słodyczą! Nie ujrzę także Pana i Boga mego, i Stwórcy, pójdę bowiem do ziemi, z której zostałem wzięty. Miłosiernie szczodry, wołam do Ciebie: Zmiłuj się nade mną, upadłym!” („Stichira na Chwała na Panie wołam”). Tym samym Kościół przypomina, że przyczyną wygnania z Edenu było nieposłuszeństwo wobec przykazania Bożego oraz brak zachowania wstrzemięźliwości. Zob. „Synaksarion 
Z kolei słowami Listu do Rzymian Kościół w tę niedzielę definiuje, czym w istocie powinien być ten szczególny okres. Paweł traktuje go bowiem jako czas powstania z grzesznego snu, oddalenia się nocy i jednocześnie nastania prawdziwego dnia, wzywa do odrzucenia uczynków ciemności i przyobleczenia się w zbroję światła, jak również życia w przyzwoitości, nie zaś „w hulankach i pijatykach, rozpuście, kłótni czy zazdrości" (Rz 13,13; zob. 13,11-14,4).

\section{Zakończenie}

Każdy z wyżej wymienionych dni na swój sposób przybliża wiernych do najbardziej wyjątkowego okresu w roku, jakim jest Wielki Post, którego apogeum stanowi Wielka Sobota, wprowadzająca w radość Paschy. Jednym z głównych celów tego okresu jest spotkanie ze Zmartwychwstałym Chrystusem. Nieodzownym krokiem na tej drodze okazuje się przygotowujący do niej „duchowy proces”.

Po analizie powyższych perykop ewangelicznych i ich kolejności nasuwają się następujące wnioski. Przekroczenie progu Wielkiego Postu wymaga od wiernych odważnego, „Zacheuszowego” dążenia do spotkania z Bogiem, jak też pokornego usposobienia celnika przy jednoczesnym odrzuceniu pysznego egoizmu faryzeusza. Nieodzownym w tym aspekcie jest również miłosierne ojcowskie serce i walka z zazdrością starszego brata z przypowieści o synu marnotrawnym, które pomogą znaleźć się po stronie sprawiedliwych po Chrystusowej paruzji. Drogowskazem w dążeniu do tego celu zawsze będzie życie w zgodzie z drugim człowiekiem.

\section{Bibliografia}

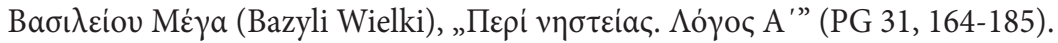

Biblia Tysiaclecia. Pismo święte Starego i Nowego Testamentu, wyd. 5 (Poznań: Pallottinum 2000). Blaza, M., „Karnawał jako przygotowanie do Wielkiego Postu?”, https://opoka.org.pl/biblioteka/T/TA/TAL/karnawal_wp.html [dostęp: 13.10.2020].

Bluj, J., „Głębokie spojrzenie”, https://info.dominikanie.pl/2016/10/dominikanskie-kazania-na-xxxi-niedziele-zwykla-2016/ [dostęp 06.06.2020].

Bondaruk, K., „Niedziela Darowania Win”, https://wiadomosci.cerkiew.pl/news.php?id_n=2220 [dostęp: 07.10.2020].

Ignacy Brianczaninow, „Rozważania w niedzielę o synu marnotrawnym”, Wiadomości Polskiego Autokefalicznego Kościoła Prawosławnego 2(363) (2020) 2-3.

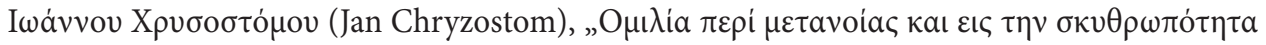

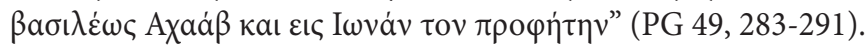


„Katyzma poetycka po 3 pieśni kanonu”, http://www.liturgia.cerkiew.pl/pages/File/docs/triod-02-przedposcie[2].pdf [dostęp: 06.10.2020].

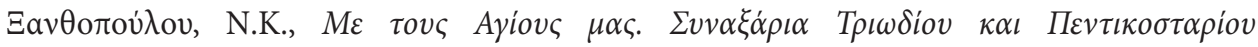

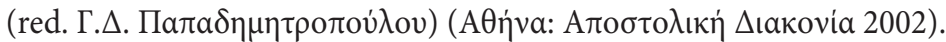

Кекелидзе, К., Иерысалимский Канонар VII века (Тифлис 1912).

Kobeszko, Ł., „Przedpoście: zapomniany i nietypowy czas pomiędzy karnawałem a postem”, https://pl.aleteia.org/2020/02/12/przedposcie-zapomniany-i-nietypowy-czas-pomiedzy-karnawalem-a-postem/ [dostęp: 06.10.2020].

Magruk, A., „Teologiczno-liturgiczny wymiar ostatniej niedzieli przygotowawczej do Wielkiego Postu w Kościele Prawosławnym", Studia Nauk Teologicznych PAN 14 (2019) 205-216.

Modrzewska, E., „Wielki post w tradycji prawosławnej”, Zeszyt Naukowy. Seria Geograficzno-Turystyczna 2 (2000) 195-215.

Nektariusz (Antonopulos), Powrót. Nawrócenie i spowiedź (Hajnówka: Bratczyk 2006).

Никулина, Е.Н., Богослужебный устав и гимнография (Москва: Православный Свято-Тихоновский Гуманитарный Университет 2019).

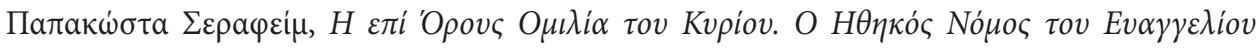

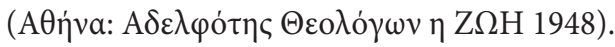

Schmemann, A., Wielki Post (Białystok: Orthdruk 2019).

„Stichira na Chwała na Panie wołam”, http://www.liturgia.cerkiew.pl/pages/File/docs-/triod-02-przedposcie[2].pdf [dostęp: 07.10.2020].

„Synaksarion niedzieli seropustnej”, http://www.liturgia.cerkiew.pl/pages/File/docs/synaksarion-09-seropust.pdf [dostęp: 05.05.2020].

Świeżyński, A., „Hermeneutyczna próba rekonstrukcji ontologii upadłego anioła na podstawie biblijnej historii upadku człowieka (Rdz 3,1-5.14-15)", Angelológia a jej súčasné interpretcie (red. A. Adam) (Banská Bystrica - Badín: Kňazský seminár sv. Františka Xaverského 2009) 101-114.

„W Świętą i Wielką Niedzielę Paschy. Jutrznia. Hymn po 6 pieśni kanonu”, http://www.liturgia.cerkiew.pl/pages/File/docs/n-02-tydzien-paschalny.pdf [dostęp: 08.06.2020].

Виссарион, Толкование на паримии (С-Петербург: Синодальная Типография 1894) II. 